\section{Commentary: The decisive alpha-galactosyl hurdle after bioprosthesis implantation}

\author{
Ari A. Mennander, MD, PhD
}

Occasionally, the wary patient referred for cardiac valve replacement inquires about the risk of bioprosthesis degeneration. The animal-borne device represents modern medical high technology, including manufactured tissue protection often by glutaraldehyde, but degeneration of a bioprosthesis remains a time-dependent threat. Where can we draw the theoretical line between chronic rejection-like degradation, allergy-associated sensitization, and inflammation-related degeneration of a bioprosthesis?

Medical products, bioprostheses, and even drugs may contain animal-derived components, such as alphagalactosyl (alpha-gal) antigens, a finding that received much renewed attention in the early 1990s. Alpha-gal antigens are present in all mammals except humans and primates. ${ }^{1}$ Thus, these antigens are foreign from the human standpoint, and humans develop antibodies that may induce even a systematic alpha-gal syndrome. ${ }^{2}$ Humans exposed to alpha-gal antigens may become sensitized even after a tick bite and develop high titers of immunoglobulin by a persistent antibody-mediated inflammation. ${ }^{2}$

In this issue of the Journal, Kuravi and colleagues ${ }^{3}$ report the results of testing various mammalian derived tissues including decellularized patches that were tested using serum from patients with known alpha-gal syndrome and sensitized reaction against alpha-gal antigens. The diagnosis of alpha-gal syndrome was based on clinical symptoms and high serum alpha-gal immunoglobulin titer. Immunoblot and immunohistochemistry techniques were

\footnotetext{
From the Tampere University Heart Hospital and Tampere University, Tampere, Finland.

Disclosures: The author reported no conflicts of interest.

The Journal policy requires editors and reviewers to disclose conflicts of interest and to decline handling or reviewing manuscripts for which they may have a conflict of interest. The editors and reviewers of this article have no conflicts of interest.

Received for publication April 5, 2021; revisions received April 5, 2021; accepted for publication April 6, 2021; available ahead of print April 20, 2021.

Address for reprints: Ari A. Mennander, MD, PhD, Tampere University Heart Hospital, Teiskontie 35, SDSKIR, PL 2000, Tampere, Finland (E-mail: ari.mennander@ sydansairaala.fi).

J Thorac Cardiovasc Surg 2022;164:e425-6

$0022-5223 / \$ 36.00$

Copyright (c) 2021 by The American Association for Thoracic Surgery

https://doi.org/10.1016/j.jtcvs.2021.04.008
}

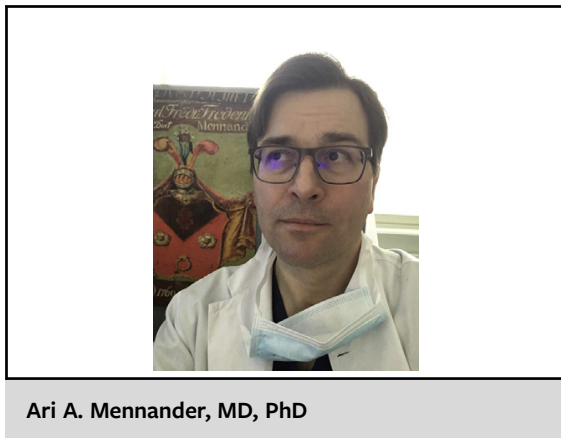

CENTRAL MESSAGE

Immunoreactivity against animal-

borne alpha-galactosyl antigens

may elaborate some of the

degenerative process of

bioprostheses.

used. Knockout pigs without alpha-gal antigens served as controls.

It was found that even decellularization did not entirely wash out the alpha-gal antigens still present in the animalderived products. ${ }^{3}$ Serum from alpha-gal syndrome patients was capable of forming an antibody-mediated reaction against these decellularized materials. The authors speculate whether patients sensitized against alpha-gal antigens undergoing cardiac surgery develop early degeneration of implanted bioprostheses and remote tissue, such as coronary arteries.

What might be the clinical significance of a very small alpha-gal antigen presentation? Is this an indication of minor immunoreactivity against alpha-gal antigens? What would be the threshold value for the anti-alpha-gal antigen concentration to signify irreversible deterioration of an implanted tissue graft? Would it be possible to quantify the antigen concentrations and the anti-alpha-gal reaction in various tissues and patients before surgery? Do specific inflammatory cells or coagulation cascades have a role together with tissue alpha-gal antigens? Why aren't all immunoglobulins activated after serum contact with alpha-gal antigens?

This in vitro study investigated the immunoreactivity of some biological and not so biological tissue, such as decellularized material. A universal alpha-gal immune reaction may endanger the outcome of bioprostheses, because these are manufactured from pig or bovine tissue., 
Scientific and experimental research is necessary to investigate for possible side effects due to an increased number of implanted bioprostheses. Would the diseased aortic valve remnant after transcatheter aortic valve replacement be an additional degenerative threat to the bioprosthesis containing alpha-gal compared with a procedure including complete excision and revision of the inflammatory aortic valve? The association of alpha-gal immunoreactivity with xenograft calcification remains enigmatic, since the grafts are usually imbedded in glutaraldehyde. On the other hand, homografts without alpha-gal antigens also degrade. Although decellularization intends to eliminate alpha-gal antigens, a process including glutaraldehyde fixation may trigger the onset of tissue degeneration as well. ${ }^{6}$

\section{References}

1. Cooper DK, Good AH, Koren E, Oriol R, Malcolm AJ, Ippolito RM, et al. Identification of alpha-galactosyl and other carbohydrate epitopes that are bound by human anti-pig antibodies: relevance to discordant xenografting in man. Transpl Immunol. 1993;1:198-205.

2. Young I, Prematunge C, Pussegoda K, Corrin T, Waddell L. Tick exposures and alpha-gal syndrome: a systematic review of the evidence. Ticks Tick Borne Dis. 2021; 12:101674.

3. Kuravi KV, Sorrells LT, Nellis JR, Rahman F, Walters AH, Matheny RG, et al. Allergic response to medical products in patients with alpha-gal syndrome. $J$ Thorac Cardiovasc Surg. 2022;164:e411-24.

4. McGregor CGA, Carpentier A, Lila N, Logan JS, Byrne GW. Cardiac xenotransplantation technology provides materials for improved bioprosthetic heart valves. J Thorac Cardiovasc Surg. 2011;141:269-75.

5. Konakci KZ, Bohle B, Blumer R, Hoetzenecker W, Roth G, Moser B, et al. Alphagal on bioprostheses: xenograft immune response in cardiac surgery. Eur J Clin Invest. 2005;35:17-23.

6. Umashankar PR, Mohanan PV, Kumari TV. Glutaraldehyde treatment elicits toxic response compared to decellularization in bovine pericardium. Toxicol Int. 2012; 19:51-8.
See Article page e411.

\section{Commentary: Alpha-gal syndrome and cardiac implant durability}

\author{
Sumner E. Kilmarx, AB, ${ }^{a}$ and Leora B. Balsam, $\mathrm{MD}^{\mathrm{b}}$
}

Recent studies have increased our understanding of the downstream effects of an underappreciated food allergy known as alpha-gal syndrome (AGS). This delayed hypersensitivity, first described by Platts-Mills in 2007 as a red meat allergy, is manifested by chronic vague gastroenteritis, malaise, and even anaphylaxis when IgE-sensitized patients are exposed to the alpha-gal antigen. ${ }^{1,2}$ Alpha-gal is a cell membrane carbohydrate ubiquitously expressed in all mammals except humans and primates, making it the most common cause of food allergy in endemic regions, such as the southeastern United States. ${ }^{3}$ In this issue of the Journal,

From the ${ }^{\mathrm{a}}$ University of Massachusetts Medical School, Worcester, Mass; and ${ }^{\mathrm{b}}$ Division of Cardiac Surgery, UMass Memorial Medical Center, Worcester, Mass.

Disclosures: The authors reported no conflicts of interest.

The Journal policy requires editors and reviewers to disclose conflicts of interest and to decline handling or reviewing manuscripts for which they may have a conflict of interest. The editors and reviewers of this article have no conflicts of interest.

Received for publication April 13, 2021; revisions received April 13, 2021; accepted for publication April 15, 2021; available ahead of print April 20, 2021.

Address for reprints: Leora B. Balsam, MD, Division of Cardiac Surgery, UMass Memorial Medical Center, University Campus, 55 Lake Ave North, Worcester, MA 01655 (E-mail: leora.balsam@umassmemorial.org).

J Thorac Cardiovasc Surg 2022;164:e426-7

$0022-5223 / \$ 36.00$

Copyright (c) 2021 by The American Association for Thoracic Surgery

https://doi.org/10.1016/j.jtcvs.2021.04.038
Check for updates

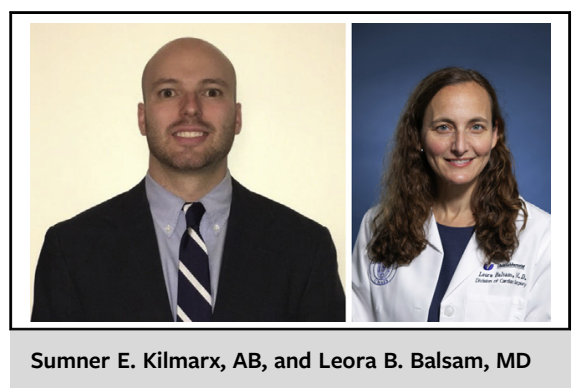

CENTRAL MESSAGE

A new study demonstrates

immunoreactivity to animal-

derived implants in patients with

a common food allergy. Less

immunogenic materials may

extend implant longevity.

Kuravi and colleagues ${ }^{4}$ demonstrate that serum from patients with AGS has high immunoreactivity against commercially available animal-derived products, including commonly used cardiac implants, such as decellularized bovine pericardium, porcine bioprosthetic valves, and bovine pericardial valves in vitro. They hypothesize that this immune reaction may lead to chronic inflammation that negatively impacts the durability of implants that carry the alpha-gal antigen. If this is so, then development of implants that specifically lack the antigen may improve longevity in vivo. 